Article

\title{
Study on Visible Light Catalysis of Graphite Carbon Nitride-Silica Composite Material and Its Surface Treatment of Cement
}

\author{
Weiguang Zhong ${ }^{\mathbb{D}}$, Dan Wang, Congcong Jiang, Xiaolei Lu, Lina Zhang * and Xin Cheng * \\ Shandong Provincial Key Laboratory of Preparation and Measurement of Building Materials, University of \\ Jinan, Jinan 250022, China; 20172120540@mail.ujn.edu.cn (W.Z.); mse_wangd@ujn.edu.cn (D.W.); \\ mse_jiangcc@ujn.edu.cn (C.J.); mse_luxl@ujn.edu.cn (X.L.) \\ * Correspondence: mes_zhangln@ujn.edu.cn (L.Z.); mse_chengx@ujn.edu.cn (X.C.)
}

Received: 24 May 2020; Accepted: 5 June 2020; Published: 7 June 2020

\begin{abstract}
Cement-based composite is one of the essential building materials that has been widely used in infrastructure and facilities. During the service of cement-based materials, the performance of cement-based materials will be affected after the cement surface is exposed to pollutants. Not only can the surface of cement treated with a photocatalyst degrade pollutants, but it can also protect the cement-based materials from being destroyed. In this study, graphite carbon nitride-silica composite materials were synthesized by thermal polymerization using nanosilica and urea as raw materials. The effect of nanosilica content and specific surface area were investigated with the optimal condition attained to be $0.15 \mathrm{~g}$ and $300 \mathrm{~m}^{2} / \mathrm{g}$, respectively. An X-ray diffractometer, thermogravimetric analyzer, scanning electron microscope, a Brunauer-Emmett-Teller (BET) specific surface area analyzer and ultraviolet-visible spectrophotometer were utilized for the characterization of as-prepared graphite carbon nitride-silica composite materials. Subsequently, the surface of cement-based materials was treated with graphite carbon nitride-silica composite materials by the one-sided immersion and brushing methods for the study of photocatalytic performance. By comparing the degradation effect of Rhodamine B, it was found that the painting method is more suitable for the surface treatment of cement. In addition, through the reaction of calcium hydroxide and graphite carbon nitride-silica composite materials, it was found that the combination of graphite carbon nitride-silica composite materials and cement is through C-S-H gel.
\end{abstract}

Keywords: graphite carbon nitride; silica; visible light catalysis; cement

\section{Introduction}

In recent years, with the continuous improvement of the level of economic development and industrialization, pollution has become more and more serious, and the environment has been greatly damaged and even threatens human health [1,2]. In order to counter these problems, photocatalytic technology has attracted widespread attention as one of the most promising methods for controlling environmental pollution [3-6]. As the most widely used civil engineering material, cement-based composite is widely used in the construction sector in various countries and regions. It has been suggested to combine photocatalytic technology with building materials [7-10]. Based on building materials, photocatalytic catalysts are easily excited by the energy of sunlight and can degrade surrounding pollutants [11-13]. So far, many efforts have been made to combine $\mathrm{TiO}_{2}$ photocatalysts with cement $[14,15]$ to achieve photocatalytic degradation capabilities [16-18] and self-cleaning capabilities [19-23]. With the deepening of research, the emergence of some problems has also hindered the development of titanium dioxide photocatalytic cement [24,25]. First, $\mathrm{TiO}_{2}$ with a wide band gap 
( $3.2 \mathrm{eV}$ ) cannot use visible light. Most of the energy of sunlight cannot be used by it, which causes energy to be wasted. Second, after the photocatalyst is coated on the cement surface, the binding between the catalyst and the cement is poor, which will cause the catalyst to fall off during use and thus reduce the photocatalytic efficiency. Therefore, a new type of visible light photocatalytic cement with a stable structure should be designed to solve the above problems.

As for the first problem, although there are a large number of methods reported to extend the spectral response range of photocatalysts [26-28], there have been few reports applied to cement materials so far. This may be due to their low activity and poor stability. However, the combination of cement and visible light photocatalysis technology will be an indispensable new requirement for the construction industry. Fortunately, graphite carbon nitride $\left(\mathrm{g}-\mathrm{C}_{3} \mathrm{~N}_{4}\right)$ has been discovered as a stable visible light photocatalyst since 2008 [29]. Due to its narrow band gap (2.7 eV), g- $\mathrm{C}_{3} \mathrm{~N}_{4}$ can make full use of visible light for photocatalytic water decomposition [30-32], organic matter degradation [33,34], and outdoor pollution control [35-37]. In contrast to traditional visible light photocatalysts, $g-C_{3} \mathrm{~N}_{4}$ is a polymer semiconductor similar to graphene and has good chemical and thermal stability $[38,39]$.

Regarding the second problem, some scholars have prepared a $\mathrm{SiO}_{2} / g-\mathrm{C}_{3} \mathrm{~N}_{4}$ [40] composite material by heating a mixture of $\mathrm{SiO}_{2}$ and melamine. The specific surface area of the obtained composite material increases, and the degree of aggregation of the graphite carbon nitride decreases. This can improve the catalyst's adsorption of pollutants so that the $\mathrm{SiO}_{2} / \mathrm{g}-\mathrm{C}_{3} \mathrm{~N}_{4}$ composite has higher activity in the process of the photocatalytic degradation of pollutants. In addition, highly reactive nanosilica can react with cement to produce C-S-H gel. The functional layer and the cement matrix are combined by C-S-H gel [41]. This provides a way to counter the problem of bonding.

In this paper, by controlling the specific surface area and the additional amount of nanosilica, the optimal preparation conditions of graphite carbon nitride-silica composite materials are discussed. The effect of nanosilica on the modification of graphite carbon nitride is explored by XRD, TGA SEM, UV-Vis, and Brunauer-Emmett-Teller (BET) methods. Subsequently, the prepared graphite carbon nitride-silica composite material is used to treat the cement surface, and its photocatalytic ability is studied by degrading the dye under visible light. At the same time, the reaction mechanism of graphite carbon nitride-silica composite material and calcium hydroxide is explored.

\section{Materials and Methods}

\subsection{Materials}

Rhodamine B (RhB) and urea were purchased from Sinopharm Chemical Reagent Co. Ltd. (Shanghai, China) without any purification. RhB was prepared as a $10 \mathrm{mg} / \mathrm{l}$ solution for use. Nanosilica was purchased from Aladdin Reagent Co. Ltd. (Shanghai, China). Its specific surface areas are 200 and $300 \mathrm{~m}^{2} / \mathrm{g}$, respectively. P.W 525 white cement was purchased from Shandong Shanshui Cement Co. Ltd. (Jinan, Shandong, China). Its density is $3.2 \mathrm{~g} / \mathrm{cm}^{3}$. Distilled water obtained from a water purification system (Direct-Q ${ }^{\circledR}$ 3.5.8, Millipore Co. Ltd., Burlington, MA, USA).

\subsection{Preparation of Graphite Carbon Nitride-Silica Composite Materials}

First, $50 \mathrm{~mL}$ deionized water was added to a $100 \mathrm{~mL}$ crucible. Nanosilica with a specific surface area of $200 \mathrm{~m}^{2} / \mathrm{g}$ was then added to the crucible. The amount of nanosilica added was controlled to $0.05 \mathrm{~g}, 0.10 \mathrm{~g}, 0.15 \mathrm{~g}$, and $0.20 \mathrm{~g}$. The nanosilica solution was sonicated for $30 \mathrm{~min}$ by using an ultrasonic cell grinder. The purpose was to uniformly disperse the nanosilica in deionized water, and then $12 \mathrm{~g}$ urea was added to the crucible. After stirring for $30 \mathrm{~s}$ with a glass rod, the crucible was placed in an ultrasonic cleaning machine for $30 \mathrm{~min}$ for ultrasonic treatment, with the purpose to completely dissolve the urea. After the treatment, the crucible was dried in an oven at $70{ }^{\circ} \mathrm{C}$. After drying, the crucible was taken out; the crucible mouth was covered with aluminum foil paper, and the crucible lid was covered. The crucible was placed in a muffle furnace and heated to $550{ }^{\circ} \mathrm{C}$ in an air atmosphere. The temperature increase rate was $5^{\circ} \mathrm{C} / \mathrm{min}$, and the holding time was $2 \mathrm{~h}$. 
The obtained graphite carbon nitride-silica composite material $\left(\mathrm{g}-\mathrm{C}_{3} \mathrm{~N}_{4}-\mathrm{SiO}_{2}\right)$ was taken out from the crucible after natural cooling, and it could then be used after grinding. By adjusting the specific surface area of $\mathrm{SiO}_{2}$ to $300 \mathrm{~m}^{2} / \mathrm{g}$, several other samples were prepared by the same method. It was named CS005-200, CS011-200, CS015-200, CS020-200, CS005-300, CS010-300 CS015-300, CS020-300 according to the amount and specific surface area of nanosilica.

\subsection{Characterization of $\mathrm{g}-\mathrm{C}_{3} \mathrm{~N}_{4}-\mathrm{SiO}_{2}$}

The crystal structure of the sample was determined by an X-ray diffractometer (XRD, D8 Advance, Bruker Co. Ltd., Karlsruhe, Ban-Württemberg, Germany). A thermal gravimetric analyzer (TGA/DSC 1, Mettler, Switzerland) was used to determine the sample composition. The field emission scanning electron microscope (QUANTA 250 FEG, FEI Co. Ltd., Hillsboro, OR, USA) was used to observe the micromorphology of the samples. Its acceleration voltage is $20 \mathrm{kV}$. The band gap was characterized by a UV-Vis DRS spectrum by an ultraviolet-visible spectrophotometer (U-4100 Hitachi Co. Ltd., Tokyo, Japan). The photocatalytic activity of $\mathrm{g}-\mathrm{C}_{3} \mathrm{~N}_{4}-\mathrm{SiO}_{2}$ was evaluated by the degradation of $\mathrm{RhB}$ $(10 \mathrm{mg} / \mathrm{l})$ under visible light in a photo reactor (Beijing Princes Co. Ltd., Beijing, China). The light source is a xenon lamp with a power of $350 \mathrm{~W}$. The absorbance of RhB was measured by an ultraviolet-visible spectrophotometer (U-4100, Hitachi Co. Ltd., Tokyo, Japan). The degradation rate was calculated by dividing the absorbance of the sample by its original absorbance. The specific surface area was measured by the Brunauer-Emmett-Teller (BET) method using a specific surface area analysis tester (MFA-140 Beijing Peaudi Co. Ltd., Beijing, China).

\subsection{Surface Treatment of Cement with $\mathrm{g}-\mathrm{C}_{3} \mathrm{~N}_{4}-\mathrm{SiO}_{2}$}

Cement paste produced with white cement was made into a cube of $20 \mathrm{~mm} \times 20 \mathrm{~mm} \times 20 \mathrm{~mm}$ with a water-cement ratio of 0.35 . The cement sample was placed in the curing room for 7 days. The $\mathrm{g}-\mathrm{C}_{3} \mathrm{~N}_{4}-\mathrm{SiO}_{2}$ was mixed with water to make a $1 \mathrm{mg} / \mathrm{mL}$ suspension. The photocatalyst was attached to the surface of cement by the one-sided immersion method and the brushing method. For the one-sided immersion method, the flank of cement was covered with adhesive tape, and the top surface was surrounded. The suspension was sucked by using a dropper, and it was evenly dropped to the top surface. For the brushing method, the dispersion liquid was dipped by using a brush and then repeatedly brushed onto the cement surface. The treated cement samples were placed in a dark curing cabinet for 7 days. The temperature was $25^{\circ} \mathrm{C}$. The humidity was $50 \%$.

\subsection{Evaluation of Visible Light Catalytic Performance of Photocatalytic Cement}

The cement sample was taken out of the curing box. The RhB solution $(10 \mathrm{mg} / \mathrm{L})$ was sprayed evenly onto the treated surface. The sprayed cement was put in the dark for curing for $24 \mathrm{~h}$. After the RhB solution on the surface of the sample was dried, it was taken out of the curing box. It was placed in the photocatalytic reactor and the test surface was aimed at the light source. Under the condition of visible light irradiation, the picture was taken every $30 \mathrm{~min}$, and its color change was compared.

\subsection{Exploration of the Binding Mechanism of Graphite Carbon Nitride-Silicon Dioxide Composite Materials and Cement}

We added $60 \mathrm{ml}$ of a saturated calcium hydroxide solution to the plastic bottle. Then, $0.15 \mathrm{~g}$ of CS015-300 was added to the solution. After stirring evenly, the $\mathrm{pH}$ value of the solution was measured with a pH test paper. The plastic bottle was sealed, and it was stirred at $1000 \mathrm{rpm}$ on the magnetic stirrer for 7 days. After stirring, the resulting sample was taken out, and the $\mathrm{pH}$ of the solution was measured again. After the measurement was completed, the sample was dried in a vacuum drying oven, and then it was ground and tested. 


\section{Results and Discussion}

\subsection{Crystal Structure}

In order to analyze the crystal structure of the synthesized of $\mathrm{g}-\mathrm{C}_{3} \mathrm{~N}_{4}-\mathrm{SiO}_{2}$, we characterized it with an X-ray diffractometer. Figure $1 \mathrm{a}$ is the XRD pattern of $\mathrm{g}-\mathrm{C}_{3} \mathrm{~N}_{4}-\mathrm{SiO}_{2}$ synthesized with $\mathrm{SiO} 2$ with a specific surface area of $200 \mathrm{~m}^{2} / \mathrm{g}$. There is no obvious diffraction peak in the XRD pattern of $\mathrm{SiO}_{2}$, but there is a steamed bread around $2 \theta=23^{\circ}$. The reason is that gas-phase nano- $\mathrm{SiO}_{2}$ is amorphous [42]. This is also the reason why there are only two diffraction peaks of $2 \theta=12.9^{\circ}$ and $2 \theta=27.5^{\circ}$ in the XRD pattern of the $\mathrm{g}-\mathrm{C}_{3} \mathrm{~N}_{4}-\mathrm{SiO}_{2}$. Here, $2 \theta=12.9^{\circ}$ and $2 \theta=27.5^{\circ}$ correspond to the (100) and (002) crystal planes of $\mathrm{g}-\mathrm{C}_{3} \mathrm{~N}_{4}$, respectively [43]. After the addition of $\mathrm{SiO}_{2}$, the intensity of the diffraction peak at $2 \theta=12.9^{\circ}$ is weaker than that of the single $g-C_{3} N_{4}$. With the increase of the amount of $\mathrm{SiO}_{2}$ added, the intensity of the diffraction peak showed a trend of gradually decreasing. The change law of the diffraction peak intensity at $2 \theta=27.5^{\circ}$ is consistent with the change law of the diffraction peak intensity at $2 \theta=12.9^{\circ}$. This may be related to the decrease of the proportion of $\mathrm{g}-\mathrm{C}_{3} \mathrm{~N}_{4}$ when the amount of $\mathrm{SiO}_{2}$ in the sample is increased. Figure $1 \mathrm{~b}$ is the XRD pattern of g- $\mathrm{C}_{3} \mathrm{~N}_{4}-\mathrm{SiO}_{2}$ synthesized with $\mathrm{SiO}_{2}$ with a specific surface area of $300 \mathrm{~m}^{2} / \mathrm{g}$. An analysis of the changes in the diffraction peaks of the two graphs reveals that they are basically the same as those shown in Figure 1a. Their rule is that there is no change in the position of the diffraction peak, and the intensity of the same diffraction peak decreases as the amount of $\mathrm{SiO}_{2}$ added increases. This can also be attributed to the reduction of graphite carbon nitride content in the sample. From a comprehensive analysis of Figure $1 \mathrm{a}, \mathrm{b}$, it can be concluded that the change in the specific surface area of $\mathrm{SiO}_{2}$ will not affect the crystal structure of the $\mathrm{g}-\mathrm{C}_{3} \mathrm{~N}_{4}-\mathrm{SiO}_{2}$.
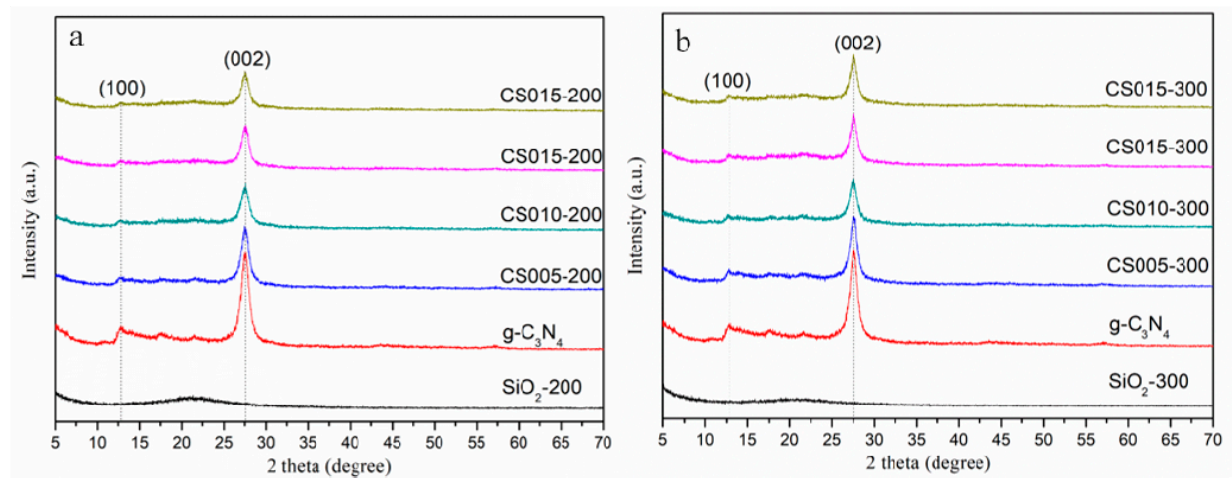

Figure 1. The XRD patterns of $\mathrm{SiO}_{2}-200, \mathrm{~g}-\mathrm{C}_{3} \mathrm{~N}_{4}, \mathrm{CS} 005-200, \mathrm{CS} 010-200, \mathrm{CS} 015-200, \mathrm{CS} 020-200$ (a) and $\mathrm{SiO}_{2}-300, g-\mathrm{C}_{3} \mathrm{~N}_{4}, \mathrm{CS} 005-300, \mathrm{CS} 010-300, \mathrm{CS} 015-300, \mathrm{CS} 020-300$ (b).

\subsection{Composition}

Figure 2 shows the TG curve of $\mathrm{SiO}_{2}, \mathrm{~g}-\mathrm{C}_{3} \mathrm{~N}_{4}$ and $\mathrm{g}-\mathrm{C}_{3} \mathrm{~N}_{4}-\mathrm{SiO}_{2}, \mathrm{CS} 005-200, \mathrm{CS} 010-200, \mathrm{CS} 015-200$, CS020-200, CS005-300, CS010-300, CS015-300, CS020-300. Below $580{ }^{\circ} \mathrm{C}$, the quality of $\mathrm{g}-\mathrm{C}_{3} \mathrm{~N}_{4}$ is basically unchanged. This shows that $\mathrm{g}-\mathrm{C}_{3} \mathrm{~N}_{4}$ has stable chemical properties below $580{ }^{\circ} \mathrm{C}$. The reason is that the internal structure is an aromatic ring conjugated system connected by a covalent bond of carbon and nitrogen. On the other hand, $\mathrm{g}-\mathrm{C}_{3} \mathrm{~N}_{4}$ has a layered structure similar to graphite. The van der Waals force between layers is relatively strong [44]. From the beginning of $580{ }^{\circ} \mathrm{C}$, as the temperature is increased, $\mathrm{g}-\mathrm{C}_{3} \mathrm{~N}_{4}$ is decomposed. The $\mathrm{g}-\mathrm{C}_{3} \mathrm{~N}_{4}$ is completely decomposed at $750{ }^{\circ} \mathrm{C}$. At this time, the mass of $\mathrm{g}-\mathrm{C}_{3} \mathrm{~N}_{4}$ is 0 . This corresponds to the position of the inflection point in the curve. $\mathrm{SiO}_{2}$ basically has no mass loss below $900^{\circ} \mathrm{C}$. It has excellent thermochemical stability below $900{ }^{\circ} \mathrm{C}$ [45]. According to the characteristics of $\mathrm{g}-\mathrm{C}_{3} \mathrm{~N}_{4}$ and $\mathrm{SiO}_{2}$ in the $\mathrm{TG}$ curve, we can determine the proportion of $\mathrm{SiO}_{2}$ in different samples according to the value of the inflection point in the curve. In CS005-200, the content of $\mathrm{SiO}_{2}$ is $16.48 \%$. In CS010-200, the content of $\mathrm{SiO}_{2}$ is 29.66\%. In CS015-200, the content of $\mathrm{SiO}_{2}$ is 31.24\%. In CSO20-200, the content of $\mathrm{SiO}_{2}$ is 35.62\%. In CS005-300, the content of 
$\mathrm{SiO}_{2}$ is $12.40 \%$. In CS010-300, the content of $\mathrm{SiO}_{2}$ is $28.41 \%$. In CS015-300, the content of $\mathrm{SiO}_{2}$ is $36.26 \%$. In $\mathrm{CS} 020-300$, the content of $\mathrm{SiO}_{2}$ is $41.28 \%$.
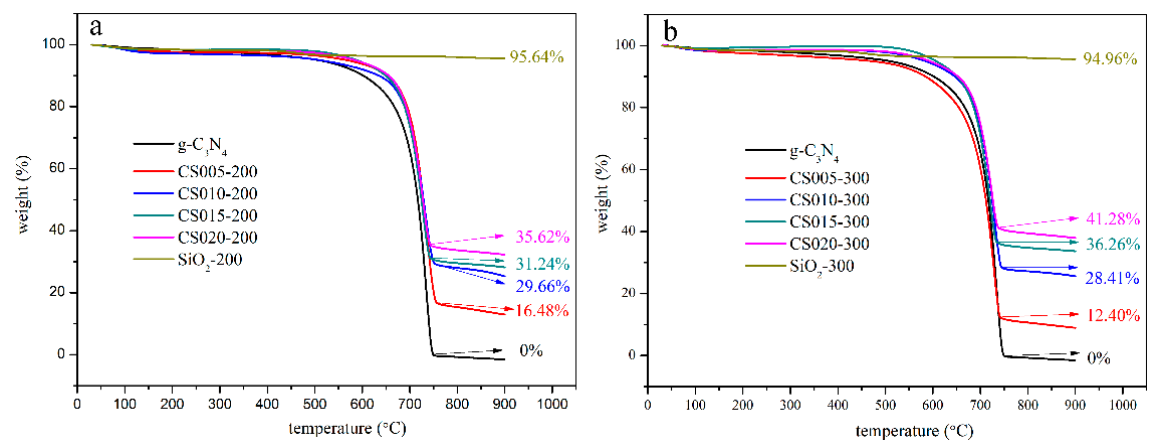

Figure 2. The TGA analysis of $\mathrm{SiO}_{2}-200, \mathrm{~g}_{-} \mathrm{C}_{3} \mathrm{~N}_{4}, \mathrm{CS} 005-200, \mathrm{CS} 010-200, \mathrm{CS} 015-200, \mathrm{CS} 020-200$ (a) and $\mathrm{SiO}_{2}-300, \mathrm{~g}^{-} \mathrm{C}_{3} \mathrm{~N}_{4}, \mathrm{CS} 005-300, \mathrm{CS} 010-300, \mathrm{CS} 015-300, \mathrm{CS} 020-300$ (b).

\subsection{Surface Morphology and Structure}

As shown in Figure 3, the structure of CS005-200 is a stacked layer. The spacing between the slices is very obvious; there are holes in the middle of the block. At the same time, there are a few spherical $\mathrm{SiO}_{2}$ particles in the middle of the block, which are attached to both sides of the part of the plate. Obviously, more spherical $\mathrm{SiO}_{2}$ particles were observed in CS010-200 than in CS005-200. The degree of stacking between the sheets becomes weak. The form is developed into a three-dimensional structure. There are more g- $\mathrm{C}_{3} \mathrm{~N}_{4}$ flakes in the sample than spherical $\mathrm{SiO}_{2}$ particles, which leads to uneven distribution. The spherical $\mathrm{SiO}_{2}$ particles in CS015-200 are evenly embedded in the holes of the g- $\mathrm{C}_{3} \mathrm{~N}_{4}$ sheet. In CS020-300, spherical $\mathrm{SiO}_{2}$ increased significantly, while g- $\mathrm{C}_{3} \mathrm{~N}_{4}$ flakes decreased. The distribution of $\mathrm{SiO}_{2}$ and $\mathrm{g}-\mathrm{C}_{3} \mathrm{~N}_{4}$ is also uneven. As the $\mathrm{SiO}_{2}$ content increases, more $\mathrm{SiO}_{2}$ particles are introduced into the pores of the $\mathrm{g}-\mathrm{C}_{3} \mathrm{~N}_{4}$ flake. When the added amount reached $0.15 \mathrm{~g}$, the $\mathrm{SiO}_{2}$ particles evenly entered the pores of the $\mathrm{g}-\mathrm{C}_{3} \mathrm{~N}_{4}$. At this time, the modification effect is the best. The amount of $\mathrm{SiO}_{2}$ continued to increase, and $\mathrm{SiO}_{2}$ was distributed on the surface. Moreover, the porosity in the sample is also reduced, which leads to a poor modification effect. The SEM changes of CS005-300, CS010-300, CS015-300, and CS020-300 are similar to those of the CS200 series. It should be noted that the holes in the CS300 series samples are smaller than those in the CS200 series. The increase in porosity will increase the specific surface area, thereby improving the photocatalytic activity. Therefore, when the specific surface area of $\mathrm{SiO}_{2}$ is $300 \mathrm{~m}^{2} / \mathrm{g} \mathrm{SiO}{ }_{2}$ and the addition amount is $0.15 \mathrm{~g}$, the obtained $\mathrm{g}-\mathrm{C}_{3} \mathrm{~N}_{4}-\mathrm{SiO}_{2}$ has the best performance. The results of the EDS analysis are shown in Figure 4. CS015-300 contains four elements of C, N, Si, and O. Both C and N come from g- $\mathrm{C}_{3} \mathrm{~N}_{4}$, while $\mathrm{Si}$ and $\mathrm{O}$ come from $\mathrm{SiO}_{2}$. This indicates that $\mathrm{g}-\mathrm{C}_{3} \mathrm{~N}_{4}-\mathrm{SiO}_{2}$ has been successfully synthesized.

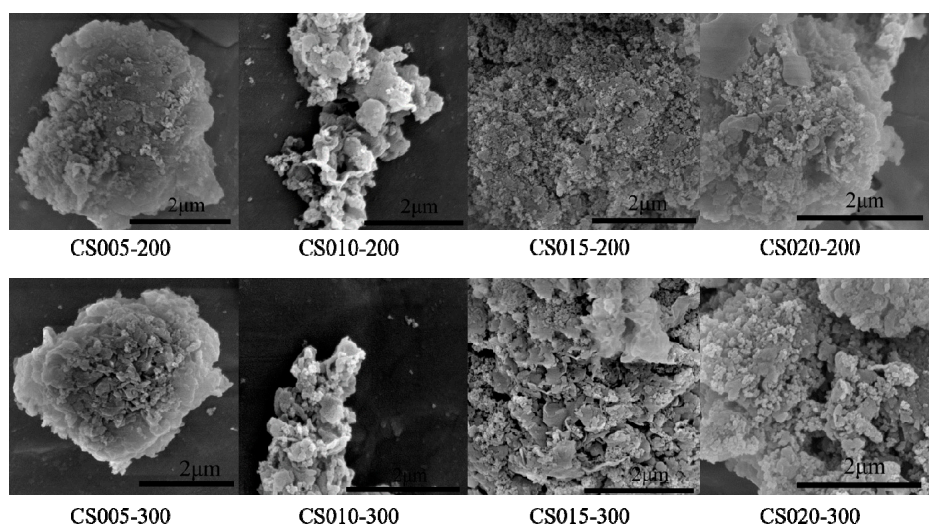

Figure 3. SEM images of CS005-200, CS010-200, CS015-200, CS020-200, CS005-300, CS010-300, CS015-300, CS020-300. 


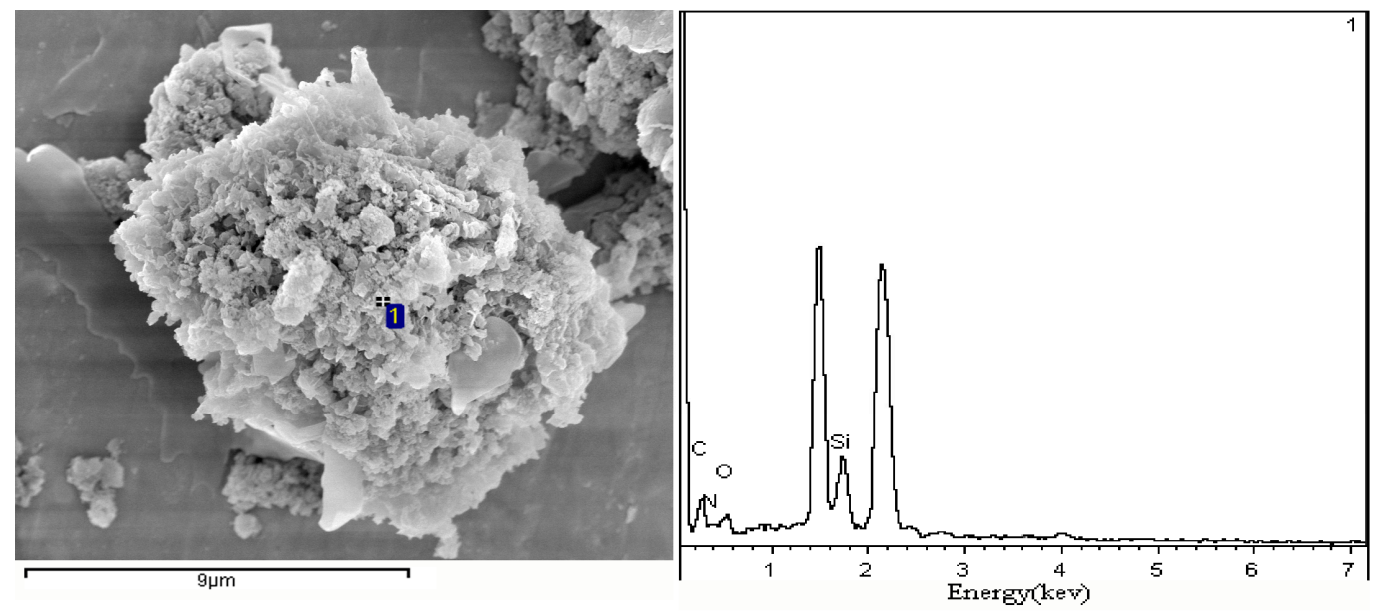

Figure 4. The EDS analysis of CS015-300.

\subsection{Specific Surface Area and Porosity}

Figure 5 is the nitrogen adsorption and desorption isotherms of $\mathrm{g}^{-} \mathrm{C}_{3} \mathrm{~N}_{4}, \mathrm{CS} 015-200$, and CS015-300. The specific surface area, the total pore volume and the average pore radius measured by the $\mathrm{N}_{2}$ adsorption-desorption experimental data and the BET model are listed in Table 1. The adsorption-desorption curves of $\mathrm{g}-\mathrm{C}_{3} \mathrm{~N}_{4}$ and CS015-300 indicate a type $\Pi$ isotherm, which is the characteristic of microporous materials. It can be seen from Table 1 that after the addition of nano- $\mathrm{SiO}_{2}$, the specific surface area of the sample became larger, the total pore volume became smaller, and the average pore radius became smaller. The specific surface area of CS015-200 was increased by $61.68 \%$, the total pore volume was expanded by $56.13 \%$, and the average pore radius was reduced by $3.41 \%$. The specific surface area of CS015-300 was increased by $126.35 \%$, the total pore volume was expanded by $15.70 \%$, and the average pore radius was reduced by $52.99 \%$. The reason is that more pores were introduced with the addition of nano- $\mathrm{SiO}_{2}$, which caused the pore volume to be reduced and the pore size to become smaller. This caused the specific surface area to be increased. Although it was concluded from the previous analysis that the addition of $\mathrm{SiO}_{2}$ has little effect on the band structure of the sample, the specific surface area has greatly improved. As the specific surface area is increased, more active sites are provided [46]. This is conducive to the improvement of catalytic capacity.

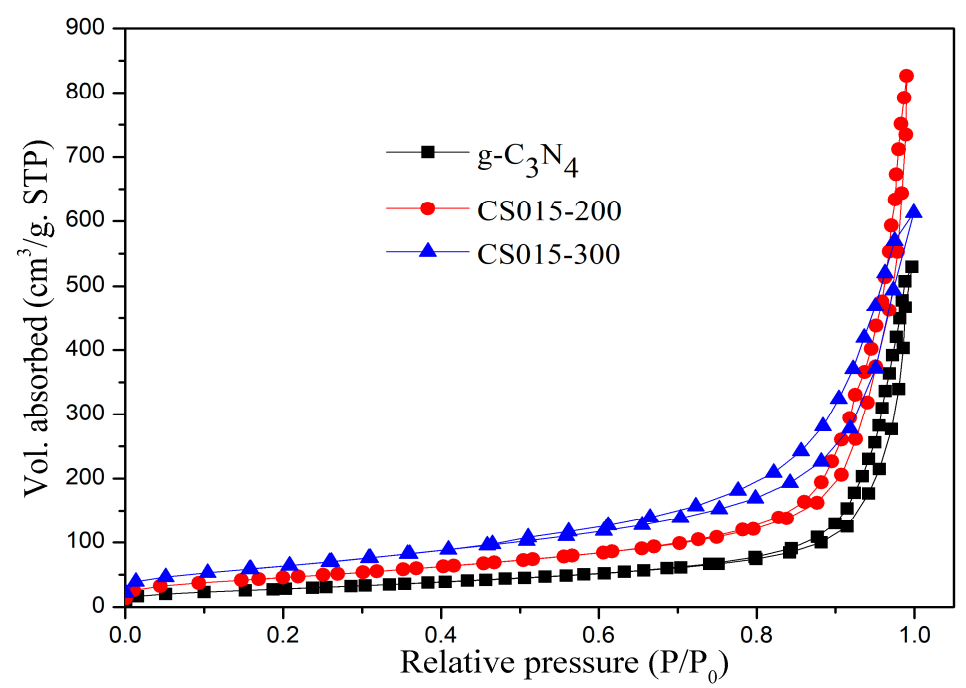

Figure 5. $\mathrm{N}_{2}$ adsorption-desorption isotherms of $\mathrm{g}-\mathrm{C}_{3} \mathrm{~N}_{4}, \mathrm{CS} 015-200$, and CS015-300. 
Table 1. The specific surface area, total pore volume, and average hole radius of $\mathrm{g}^{-} \mathrm{C}_{3} \mathrm{~N}_{4}, \mathrm{CS} 015-200$ and CS015-300.

\begin{tabular}{cccc}
\hline Sample & Specific Surface Area & Total Pore Volume & Average Hole Radius \\
\hline $\mathrm{g}-\mathrm{C}_{3} \mathrm{~N}_{4}$ & $105.45 \mathrm{~m}^{2} / \mathrm{g}$ & $0.81 \mathrm{~cm}^{3} / \mathrm{g}$ & $15.53 \mathrm{~nm}$ \\
$\mathrm{CS} 015-200$ & $170.49 \mathrm{~m}^{2} / \mathrm{g}$ & $1.27 \mathrm{~cm}^{3} / \mathrm{g}$ & $15.00 \mathrm{~nm}$ \\
$\mathrm{CS} 015-300$ & $238.68 \mathrm{~m}^{2} / \mathrm{g}$ & $0.94 \mathrm{~cm}^{3} / \mathrm{g}$ & $7.30 \mathrm{~nm}$ \\
\hline
\end{tabular}

\subsection{Band Gap and Absorption Edge}

As can be seen from Figure 6a, the UV-Vis spectral curve of CS005-200 and of CS010-200 are similar to that of $\mathrm{g}-\mathrm{C}_{3} \mathrm{~N}_{4}$. The absorption edge does not move. The absorption edge of CS015-200 has a slight red shift. The UV-Vis spectrum of CS020-200 is different from that of the previous materials; its absorption edge has a slight blue shift. Their change rule is that the UV-Vis spectrum of the sample does not change when the amount of $\mathrm{SiO}_{2}$ is low. As the amount of $\mathrm{SiO}_{2}$ is increased, the absorption edge of the sample is red-shifted, but the degree of shift is not large. As the amount of $\mathrm{SiO}_{2}$ is continuously increased, the absorption edge of the sample has a blue shift. This shows that the low additional amount of $\mathrm{SiO}_{2}$ will not affect the visible light absorption range. The addition of $\mathrm{SiO}_{2}$ will expand the visible light absorption range of the sample under the appropriate addition amount. However, when the blending amount is too large, the negative effect will appear. From Figure $6 \mathrm{~b}$, we can find that the width of the band gap of CS005-200 and CS010-200 is the same as that of $\mathrm{g}^{-} \mathrm{C}_{3} \mathrm{~N}_{4}$, both of which are $2.7 \mathrm{eV}$. The width of the forbidden band of CS015-200 was reduced to $2.65 \mathrm{eV}$, and the absorption edge was increased to $471 \mathrm{~nm}$. The band gap of CS020-200 was expanded to $2.8 \mathrm{eV}$, and the absorption edge was reduced to $468 \mathrm{~nm}$. The variation law of the band gap of each sample is the same as that of its corresponding ultraviolet-visible diffuse reflection spectrum.
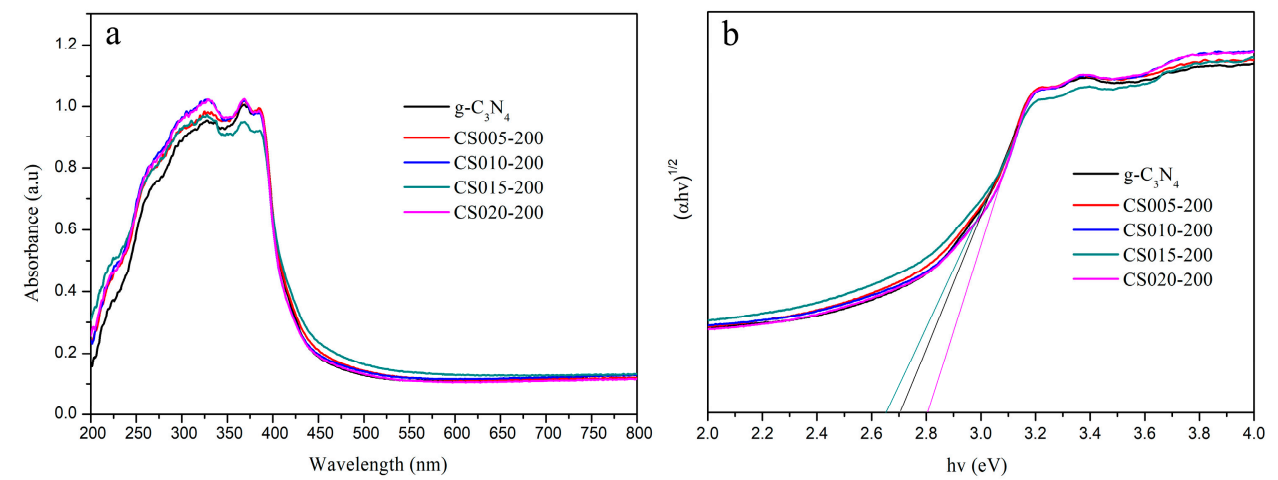

Figure 6. UV-Vis spectra (a) and band gap (b) of g- $\mathrm{C}_{3} \mathrm{~N}_{4}$, CS005-200, CS010-200, CS015-200, CS020-200.

The UV-Vis spectrum of the $\mathrm{g}-\mathrm{C}_{3} \mathrm{~N}_{4}-\mathrm{SiO}_{2}$ prepared with $\mathrm{SiO}_{2}$ with a specific surface area of $300 \mathrm{~m}^{2} / \mathrm{g}$ is shown in Figure 7a. The absorption edge of the sample changed. The absorption edge of CS005-300 and CS020-300 has a slight blue shift compared to g- $\mathrm{C}_{3} \mathrm{~N}_{4}$. The movement of CS005-300 was slightly larger than that of CS020-300. The curve of CS010-300 coincides with the curve of $g-C_{3} \mathrm{~N}_{4}$, and the absorption edge did not change. A slight red shift occurred in the absorption edge of CS015-300. The difference with the graphite carbon nitride-silica $\left(\mathrm{S}_{\mathrm{BET}}=200 \mathrm{~m}^{2} / \mathrm{g}\right)$ composite material is that the absorption edge of the sample had a blue shift at lower dosing levels and too much doping. The corresponding absorption of visible light was also reduced. From Figure $7 \mathrm{~b}$, it can be found that the band gap of CS005-300 expanded to $2.8 \mathrm{eV}$, and the absorption edge was reduced to $442 \mathrm{~nm}$. The band gaps of CS010-300 and CS015-300 were reduced to $2.68 \mathrm{eV}$, and the absorption edge expanded to $462 \mathrm{~nm}$. The band gap of CS020-300 expanded to $2.75 \mathrm{eV}$, and the absorption edge was reduced to $451 \mathrm{~nm}$. The band gap of $\mathrm{g}-\mathrm{C}_{3} \mathrm{~N}_{4}$ is still $2.7 \mathrm{eV}$. The absorption edge is $460 \mathrm{~nm}$. Because the added $\mathrm{SiO}_{2}$ is amorphous, the changes in the band gap and the absorption edge of $\mathrm{g}-\mathrm{C}_{3} \mathrm{~N}_{4}-\mathrm{SiO}_{2}$ were very 
slight. The change in band gap is due to the quantum size effect of the smaller size $g-C_{3} N_{4}$ generated on the surface of nano- $\mathrm{SiO}_{2}$ [47].
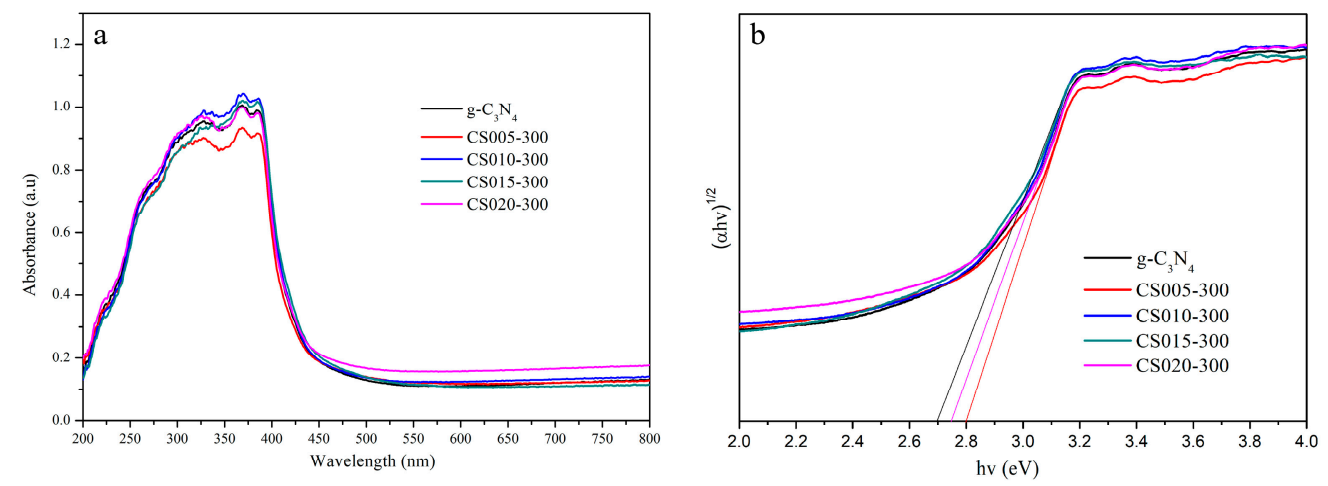

Figure 7. UV-Vis spectra (a) and band gap (b) of g- $\mathrm{C}_{3} \mathrm{~N}_{4}, \mathrm{CS} 005-300, \mathrm{CS} 010-300, \mathrm{CS} 015-300, \mathrm{CS} 020-300$.

\subsection{Photocatalytic Evaluation}

As shown in Figure 8a, RhB is not degraded without adding a catalyst. After $1 \mathrm{~h}$ of dark treatment, $\mathrm{g}-\mathrm{C}_{3} \mathrm{~N}_{4}$ has the same dye adsorption rate as the other four samples, which is about $27 \%$. With the extension of visible light exposure time, the absorbance of the dye is gradually reduced, and the dye is continuously degraded. The minimum degradation time of CS015-200 is 55 min. Secondly, the degradation time of CS005-200 is $60 \mathrm{~min}$. Thirdly, the degradation time of CS010-200 is $70 \mathrm{~min}$. Fourthly, the degradation time of $\mathrm{g}-\mathrm{C}_{3} \mathrm{~N}_{4}$ is $75 \mathrm{~min}$. The maximum degradation time of CS020-200 is $90 \mathrm{~min}$. The catalytic performance from strong to weak is ranked as CS015-200, CS005-200, CS010-200, g- $\mathrm{C}_{3} \mathrm{~N}_{4}, \mathrm{CS} 020-200$. The reason for the reduced efficiency of CS020-200 may be related to the reduced visible light absorption range caused by the reduction of the absorption edge. Among all the samples, the improvement of the CS015-200 is the most obvious, and the performance has improved by $26.67 \%$ compared with the $\mathrm{g}-\mathrm{C}_{3} \mathrm{~N}_{4}$.
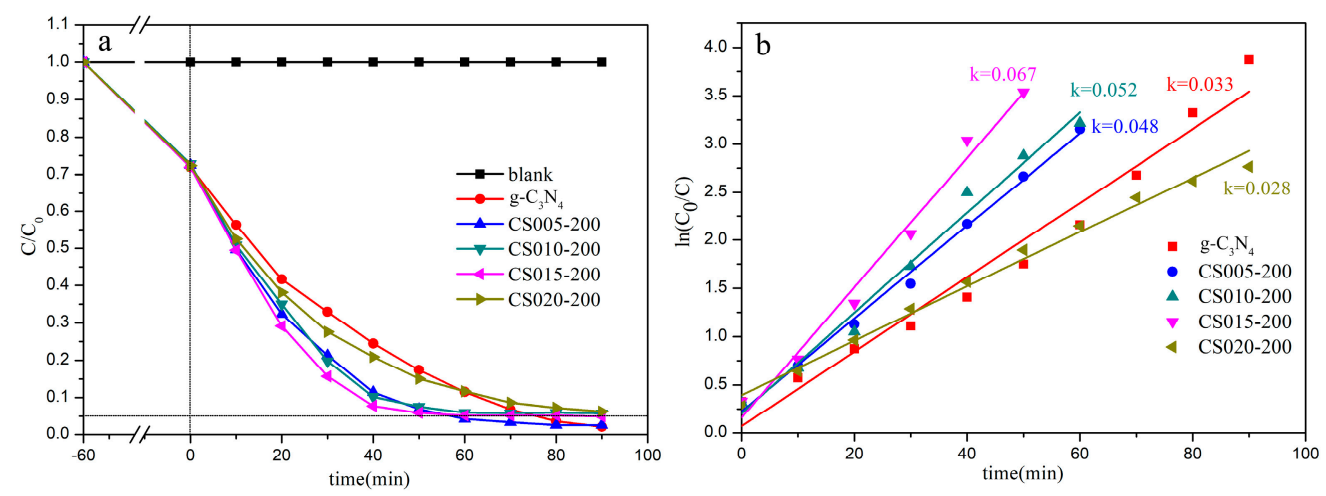

Figure 8. Photocatalytic activities (a) and their kinetic constants (b) of $\mathrm{g}_{-} \mathrm{C}_{3} \mathrm{~N}_{4}$, CS005-200, CS010-200, CS015-200, CS020-200.

From Figure $8 b$, it can be concluded that the largest $k$ value of CS015-200 is 0.067 . Secondly, the $k$ value of CS010-200 is 0.052. Thirdly, the $\mathrm{k}$ value of CS005-200 is 0.048 . Fourthly, the $\mathrm{k}$ value of $\mathrm{g}-\mathrm{C}_{3} \mathrm{~N}_{4}$ is 0.033 . The minimum $\mathrm{k}$ value of $\mathrm{CSO20-200}$ is 0.025 . After silica is added, the $\mathrm{k}$ value of each sample is changed to varying degrees. CS015-200 is $103.03 \%$ higher than $\mathrm{g}^{-} \mathrm{C}_{3} \mathrm{~N}_{4}$. CS010-200 is $57.57 \%$ higher than $\mathrm{g}_{-} \mathrm{C}_{3} \mathrm{~N}_{4}$. CS005-200 is $45.45 \%$ higher than $\mathrm{g}^{-} \mathrm{C}_{3} \mathrm{~N}_{4}$, and CS020-200 is $24.24 \%$ lower than $\mathrm{g}-\mathrm{C}_{3} \mathrm{~N}_{4}$. The performance of CS015-200 is the best among all the samples in the picture.

As shown in Figure 9a, after $1 \mathrm{~h}$ of dark treatment, different samples have different adsorption rates for dyes. The adsorption rate of composite materials is higher than that of the single $g-C_{3} N_{4}$, 
and the adsorption rate of $\mathrm{g}-\mathrm{C}_{3} \mathrm{~N}_{4}$ is about $27 \%$. The adsorption rate of CS010-300 and CS020-300 is about 33\%. The adsorption rate of CS005-300 and CS015-300 is about 39\%. The minimum degradation time of CS015-300 is $50 \mathrm{~min}$. Secondly, the degradation time of CS005-300 and CS010-300 is $60 \mathrm{~min}$. Thirdly, the degradation time of CS0020-300 is $70 \mathrm{~min}$. The maximum degradation time of $\mathrm{g}-\mathrm{C}_{3} \mathrm{~N}_{4}$ is $75 \mathrm{~min}$. The catalytic performance from strong to weak is ranked as CS015-300, CS005-300 (CS010-300), CS0020-300, g- $\mathrm{C}_{3} \mathrm{~N}_{4}$. Compared with $\mathrm{g}-\mathrm{C}_{3} \mathrm{~N}_{4}$, the visible light catalytic ability of each sample has improved. This shows that the visible light catalytic ability of the sample is increased with the addition of $\mathrm{SiO}_{2}$ with a specific surface area of $300 \mathrm{~m}^{2} / \mathrm{g}$.
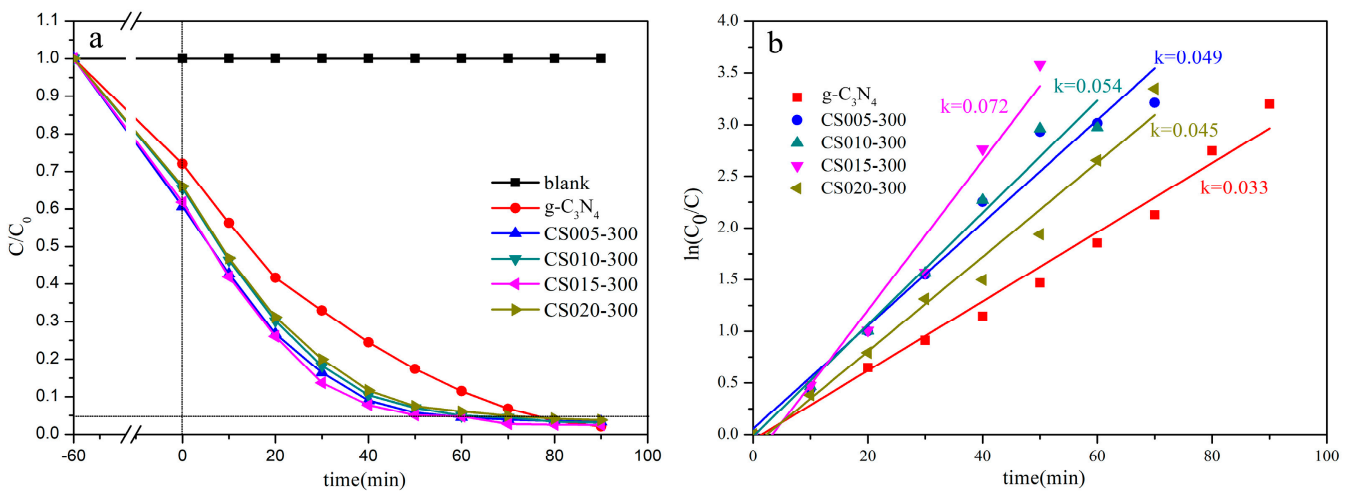

Figure 9. Photocatalytic activities (a) and their kinetic constants (b) of $g-\mathrm{C}_{3} \mathrm{~N}_{4}, \mathrm{CS} 005-300$, CS010-300, CS015-300, CS020-300.

From Figure 9b, the maximum k value of CS015-300 is 0.072. Secondly, the k value of CS010-300 is 0.054. Thirdly, the k value of CS010-300 is 0.049. Fourthly, the k value of CS020-300 is 0.045. The minimum $\mathrm{k}$ value of $\mathrm{g}-\mathrm{C}_{3} \mathrm{~N}_{4}$ is 0.033 . The difference from Figure 9 is that after adding nanosilica with a specific surface area of $300 \mathrm{~m}^{2} / \mathrm{g}$, the $\mathrm{k}$ value of all samples has improved. CS015-300 is $118.18 \%$ higher than $\mathrm{g}-\mathrm{C}_{3} \mathrm{~N}_{4}$. CS010-200 is $63.63 \%$ higher than $\mathrm{g}-\mathrm{C}_{3} \mathrm{~N}_{4}$. CS005-200 is $48.48 \%$ higher than $\mathrm{g}-\mathrm{C}_{3} \mathrm{~N}_{4}$. CS020-200 is $36.36 \%$ higher than $\mathrm{g}-\mathrm{C}_{3} \mathrm{~N}_{4}$. The performance of CS015-300 is the best among all the samples in the picture.

By comparing the degradation rate constants of the two types of samples, we find that the $g-\mathrm{C}_{3} \mathrm{~N}_{4}-\mathrm{SiO}_{2}$ prepared using $\mathrm{SiO}_{2}$ with a specific surface area of $300 \mathrm{~m}^{2} / \mathrm{g}$ has the best visible light catalytic performance. When the same amount is added, the degradation rate constant is always higher than that of $\mathrm{g}-\mathrm{C}_{3} \mathrm{~N}_{4}-\mathrm{SiO}_{2}$ prepared with $\mathrm{SiO}_{2}$ with a specific surface area of $200 \mathrm{~m}^{2} / \mathrm{g}$. In addition, the degradation rate constant of heterogeneous graphite carbon nitride-silica prepared with $\mathrm{SiO}_{2}$ with a specific surface area of $300 \mathrm{~m}^{2} / \mathrm{g}$ is higher than that of $\mathrm{g}-\mathrm{C}_{3} \mathrm{~N}_{4}$. The phenomenon of reduced catalytic performance did not occur.

\subsection{Surface Treatment Evaluation}

As can be seen from Figure 10, the catalyst distribution on the surface of the cement material treated by the one-sided immersion method is uneven, and the thickness of the coating is different. The color in the middle of the sample is obviously lighter than the color at the edge of the sample. This shows that there are more catalysts on the cement edge than in the middle. Cracking and shedding of the coating appear on the edge of the cement block. The reason is that the solution was dripping onto the cement surface, and the liquid level is affected by the surface tension; it appears to be high in the surroundings and low in the middle [48]. As the water evaporated, the water in the middle disappeared firstly and then gradually spread to the surroundings. This caused the surrounding coating to be too thick, which caused cracking and shedding. The color distribution of the surface of the cement material treated was relatively uniform by the brushing method, which indicates that the distribution of the catalyst was relatively uniform. There is no cracking and shedding of the catalyst on the cement surface, which indicates that the catalyst did not appear on the cement surface. The reason is that 
the brush dipped in less solution during the application process, and when applied to the cement surface, the surface tension is less affected. At the same time, the catalyst is further uniformly dispersed in the process of the repeated three times of brushing, thereby avoiding cracking and shedding caused by the aggregation of the catalyst.

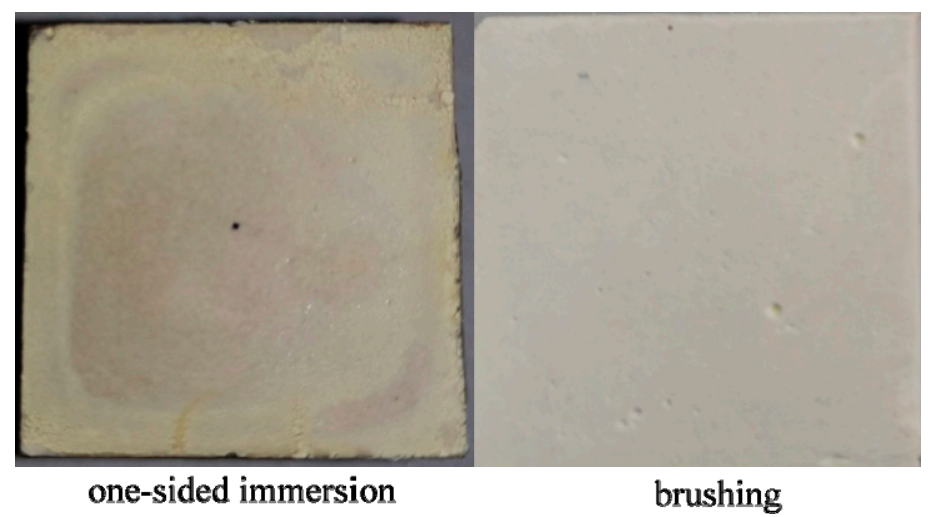

Figure 10. Surface treatment of cement by the one-sided immersion method and brushing method.

\subsection{Performance Evaluation of Photocatalytic Cement}

Figure 11 is the color change of RhB after the photocatalytic cement prepared by the one-sided immersion method was exposed to visible light. As shown in Figure 11, comparing the photos of the cement under visible light irradiation, it was found that with the increase of light time, the color of the surface without surface treatment is basically unchanged, but the color of all surface-treated samples was lightened to varying degrees. This shows that the cement had a self-cleaning function after surface treatment. The reason is that the catalyst on the cement surface captures the pollutants, and the dye was degraded under the irradiation of visible light. However, the self-cleaning efficiency of cement materials treated with different catalysts varies. After $60 \mathrm{~min}$ of irradiation, the degree of discoloration is ranked as CS015-300, CS010-300, CS005-300, CS020-300, g- $\mathrm{C}_{3} \mathrm{~N}_{4}$ in order from large to small. This is consistent with the rule of $\mathrm{g}^{-} \mathrm{C}_{3} \mathrm{~N}_{4}-\mathrm{SiO}_{2}$ degrading $\mathrm{RhB}$ in solution. This shows that the performance of the catalyst did not change after being applied to the cement surface.

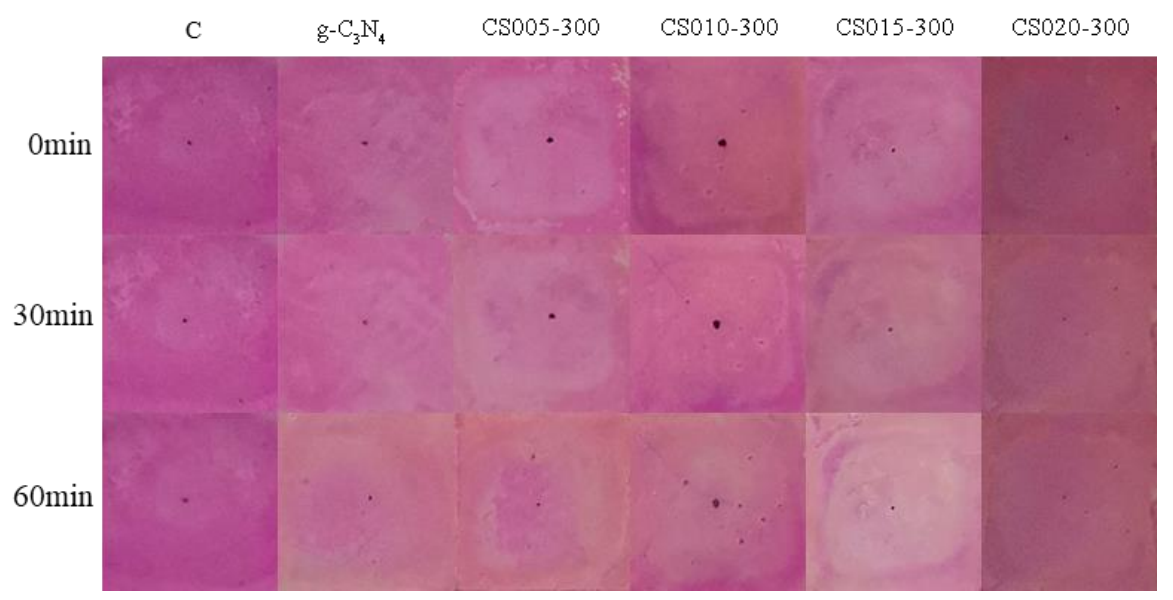

Figure 11. Photocatalytic performance of surface treatment cement with the one-sided immersion method.

Figure 12 is the color change of RhB after the photocatalytic cement prepared by the brushing method was exposed to visible light. After $60 \mathrm{~min}$ of irradiation, the degree of discoloration was ranked as CS015-300, CS010-300, CS005-300, CS020-300, $\mathrm{g}-\mathrm{C}_{3} \mathrm{~N}_{4}$ in order from large to small. The discoloration of CS015-300 is most obvious. However, since the catalyst dispersion on the cement surface treated by 
the brushing method was more uniform, the color change was more obvious than that of the one-sided immersion method. The performance of the photocatalytic cement obtained by the brushing method was more excellent.

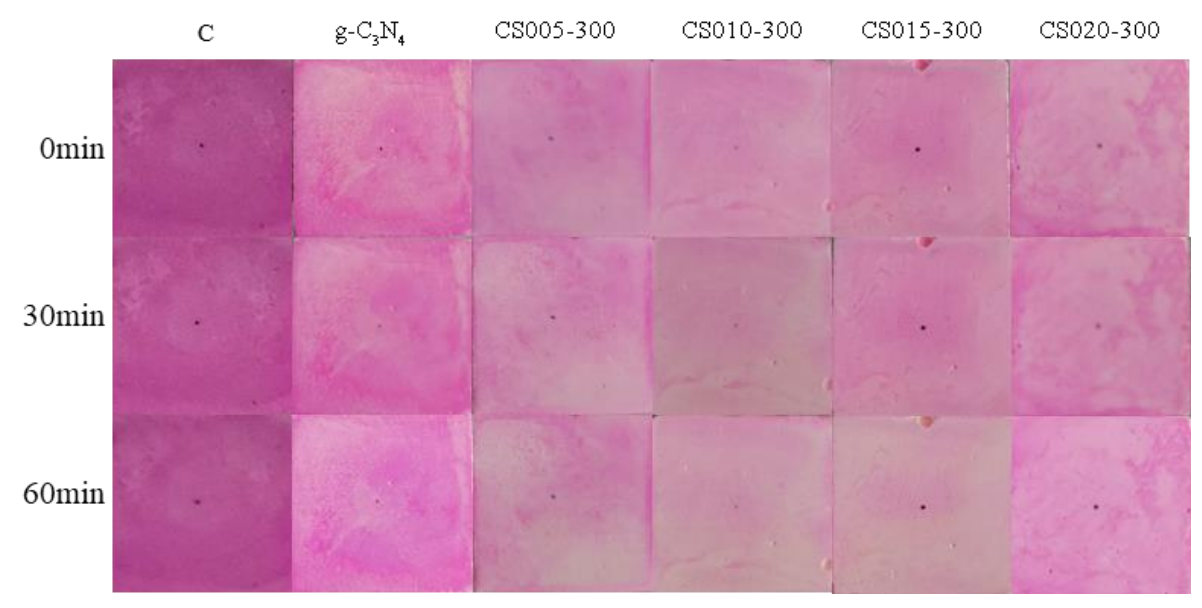

Figure 12. Photocatalytic performance of surface treatment cement by the brushing method.

\subsection{Exploration of Binding Mechanism}

In order to explore the binding mechanism of g- $\mathrm{C}_{3} \mathrm{~N}_{4}-\mathrm{SiO}_{2}$ and cement, we used saturated calcium hydroxide solution to simulate the alkaline environment of cement, and then an appropriate amount of CS015-300 was added. Under sealed conditions, the two substances are reacted. The resulting product was analyzed.

As can be seen from Figure 13, after adding CS015-300 to the saturated calcium hydroxide solution, the $\mathrm{pH}$ value of the test mixed solution is 13 . After 7 days of reaction, the $\mathrm{pH}$ of the solution was reduced to 9 . This indicates that the content of $\mathrm{OH}$ - in the solution was reduced, and a part of calcium hydroxide was reacted because $\mathrm{SiO}_{2}$ can react with calcium hydroxide by pozzolanic reaction [49]. According to existing research, it has been found that the product is C-S-H gel after the reaction $[41,50]$. We think that the nanosilica in CS015-300 reacted with the calcium hydroxide in the solution to form $\mathrm{C}-\mathrm{S}-\mathrm{H}$, and the calcium hydroxide was consumed.

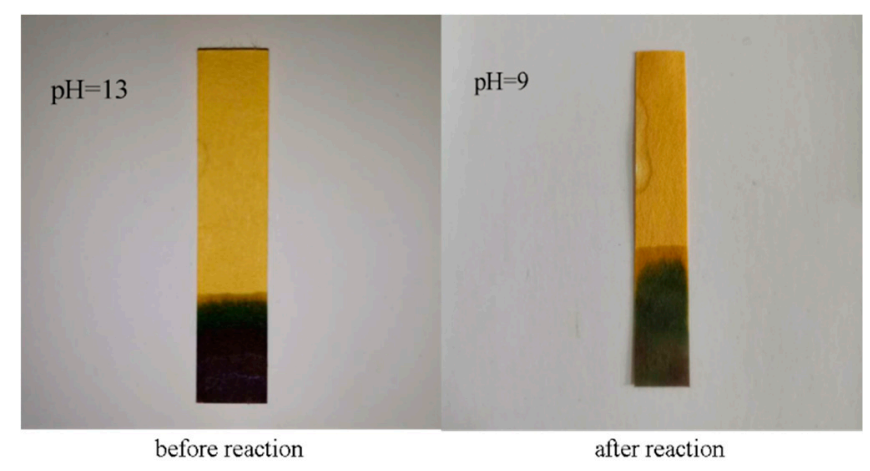

Figure 13. The $\mathrm{pH}$ of solution before and after reaction.

As can be seen from Figure 14, comparing the SEM pictures of the samples before and after the reaction, it was found that the microscopic morphology of the sample changed significantly after the reaction with calcium hydroxide. The microstructure of CS015-300 changed from the previous nanosilica embedded in the pores of $\mathrm{g}-\mathrm{C}_{3} \mathrm{~N}_{4}$ to the accumulation of irregular lumps. After further zooming, the rod was found. This point was analyzed by EDS, and the results are shown in Figure 15. It can be observed from Figure 15 that the main chemical composition of the rod is C, N, Si, O, and Ca. By analyzing the distribution of the four elements $\mathrm{C}, \mathrm{N}, \mathrm{Si}$, and $\mathrm{Ca}$ in the pink area, it was found 
that the distribution of the four elements is very uniform and no aggregation occurred. This further illustrates that CS015-300 reacted with calcium hydroxide rather than simply piled together. This can further explain that CS015-300 reacted with calcium hydroxide to form a C-S-H gel [50]. Through the simulation experiments of CS015-300 and calcium hydroxide, we can draw the conclusion that the calcium hydroxide produced by cement hydration reacts with the nanosilica in the composite material to form C-S-H gel. The g- $\mathrm{C}_{3} \mathrm{~N}_{4}-\mathrm{SiO}_{2}$ and cement material are combined by C-S-H gel.

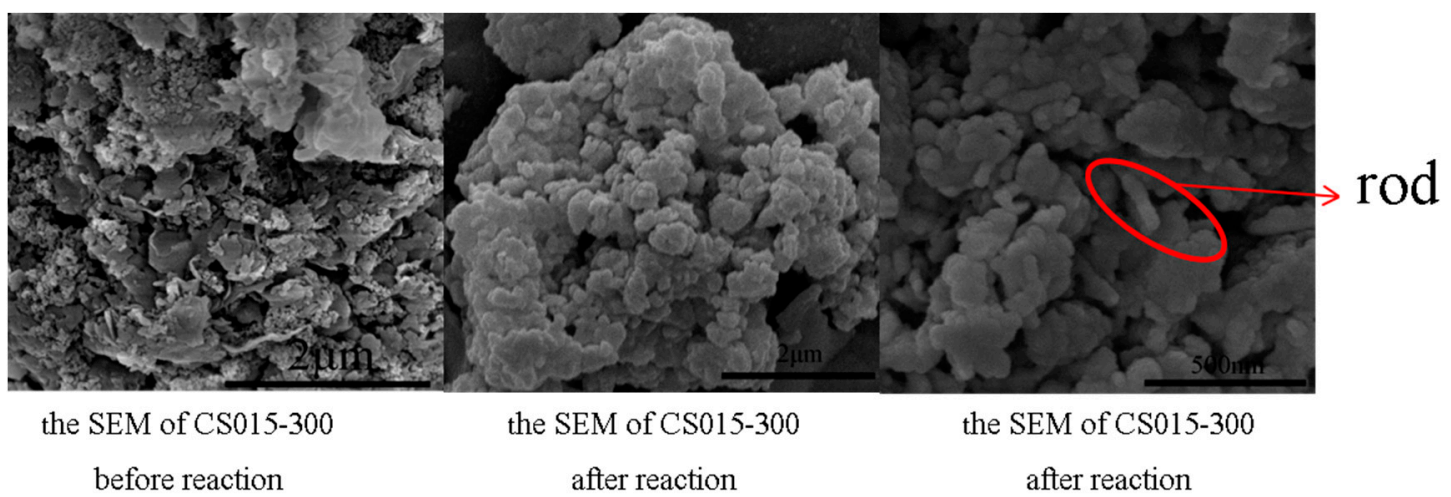

Figure 14. The SEM of CS015-300 before and after reaction.
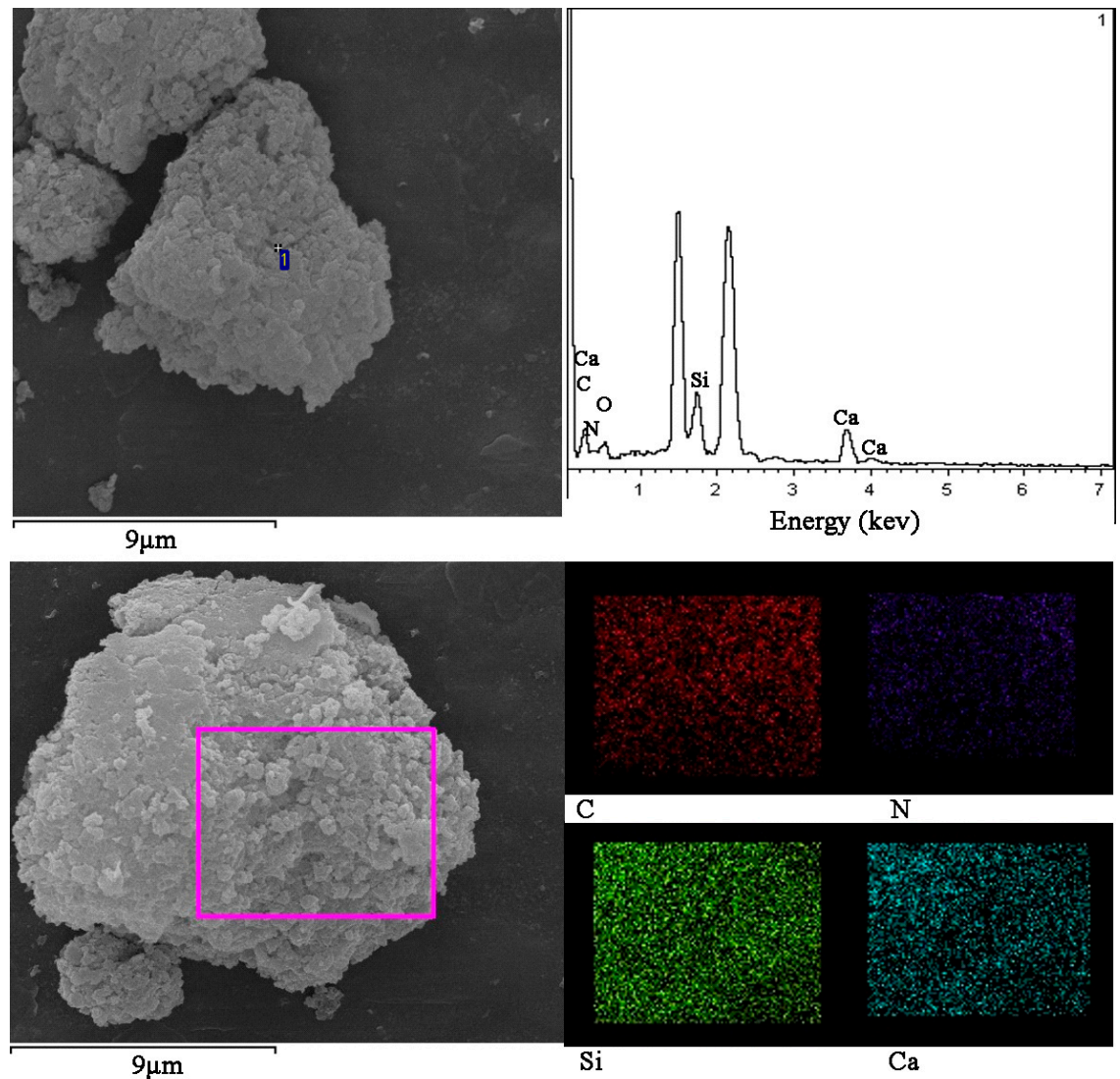

Figure 15. The EDS of CS015-300 after reaction.

\section{Conclusions}

In summary, the $\mathrm{g}-\mathrm{C}_{3} \mathrm{~N}_{4}-\mathrm{SiO}_{2}$ was synthesized by mixing and heating nanosilica and urea. By controlling the amount and the specific surface area of nanosilica, the best synthesis conditions were selected. In this way, the band gap of the graphite carbon nitride was changed, and the specific surface area was increased. The visible light catalytic performance of the material has improved. 
After the graphite carbon nitride-silicon dioxide composite material was treated by brushing and by one-sided immersion, the cement obtained the photocatalytic function. By comparing the photocatalytic efficiency, the brushing method was more suitable for the surface treatment of cement than the one-sided immersion method. The combination mechanism of calcium hydroxide and g- $\mathrm{C}_{3} \mathrm{~N}_{4}-\mathrm{SiO}_{2}$ was explored. It was found that $\mathrm{g}-\mathrm{C}_{3} \mathrm{~N}_{4}-\mathrm{SiO}_{2}$ and cement material were combined by C-S-H gel.

Author Contributions: Conceptualization: W.Z. and X.L.; methodology: all authors; validation: W.Z., D.W., and L.Z.; formal analysis: all authors; investigation: W.Z., L.Z., and C.J.; resources: all authors; writing-original draft preparation: W.Z.; writing-review and editing: all authors; visualization: all authors; supervision: all authors; project administration: L.Z.; funding acquisition: L.Z. and X.C. All authors have read and agreed to the published version of the manuscript.

Funding: This research was funded by the Program for Taishan Scholars Program, the Case-by-Case Project for Top Outstanding Talents of Jinan, the Distinguished Taishan Scholars in Climbing Plan, the Science and Technology Innovation Support Plan for Young Researchers in Institutes of Higher Education in Shandong (2019KJA017), the National Natural Science Foundation of China (Grant No. 51872121,51632003, and 51902129), the National Key Research and Development Program of China (Grant No. 2016YFB0303505) and the 111 Project of International Corporation on Advanced Cement-based Materials (No.D17001).

Acknowledgments: The authors wish to gratefully thank Shandong Provincial Key Laboratory of Preparation and Measurement of Building Materials, University of Jinan for their support of this work.

Conflicts of Interest: The authors declare no conflicts of interest.

\section{References}

1. Jafari, H.; Afshar, S. Improved photodegradation of organic contaminants using nano- $-\mathrm{TiO}_{2}$ and $\mathrm{TiO}_{2}-\mathrm{SiO}_{2}$ deposited on Portland cement concrete blocks. Photochem. Photobiol. 2016, 92, 87-101. [CrossRef] [PubMed]

2. Papoulis, D.; Kordouli, E.; Lampropoulou, P.; Rapsomanikis, A.; Kordulis, C.; Panagiotaras, D.; Theophylaktou, K.; Stathatos, E.; Komarneni, S. Characterization and photocatalytic activities of fly ash-TiO 2 nanocomposites for the mineralization of azo dyes in water. J. Surf. Interfaces Mater. 2014, 2, 261-266. [CrossRef]

3. Chen, X.; Mao, S.S. Titanium dioxide nanomaterials: Synthesis, properties, modifications and applications. Chem. Rev. 2007, 107, 2891-2959. [CrossRef]

4. Zhang, X.; Pan, J.H.; Du, A.J.; Fu, W.; Sun, D.D.; Leckie, J.O. Combination of one-dimensional $\mathrm{TiO}_{2}$ nanowire photocatalytic oxidation with microfiltration for water treatment. Water Res. 2009, 43, 1186. [CrossRef] [PubMed]

5. Canterino, M.; Somma, I.D.; Marotta, R.; Andreozzi, R.; Caprio, V. Energy recovery in wastewater decontamination: Simultaneous photocatalytic oxidation of an organic substrate and electricity generation. Water Res. 2009, 43, 2710-2716. [CrossRef] [PubMed]

6. Bhatkhande, D.S.; Pangarkar, V.G.; Beenackers, A.A.C.M. Photocatalytic degradation for environmental applications-A review. J. Chem. Technol. Biotechnol. 2002, 77, 102-116. [CrossRef]

7. Huesken, G.; Hunger, M.; Brouwers, H.J.H. Experimental study of photocatalytic concrete products for air purification. Build Environ. 2009, 44, 2463-2474. [CrossRef]

8. Lee, B.Y.; Jayapalan, A.R.; Bergin, M.H.; Kurtis, K.E. Photocatalytic cement exposed to nitrogen oxides: Effect of oxidation and binding. Cem Concr. Res. 2014, 60, 30-36. [CrossRef]

9. Maggos, T.; Plassais, A.; Bartzis, J.G.; Vasilakos, C.; Moussiopoulos, N.; Bonafous, L. Photocatalytic degradation of $\mathrm{NO}_{\mathrm{x}}$ in a pilot street canyon configuration using $\mathrm{TiO}_{2}$-mortar panels. Environ. Monit. Assess. 2008, 136, 35-44. [CrossRef]

10. Chen, M.; Chu, J. $\mathrm{NO}_{x}$ photocatalytic degradation on active concrete road surface-from experiment to real -scale application. J. Clean. Prod. 2011, 19, 1266-1272. [CrossRef]

11. Lin, H.J.; Yang, T.S.; Hsi, C.S.; Wang, M.C.; Lee, K.C. Optical and photocatalytic properties of Fe ${ }^{3+}$-doped $\mathrm{TiO}_{2}$ thin films prepared by a sol-gel spin coating. Ceram. Int. 2014, 40, 10633-10640. [CrossRef]

12. Cheng, X.; Gotoh, K.; Nakagawa, Y.; Usami, N. Effect of substrate type on the electrical and structural properties of $\mathrm{TiO}_{2}$ thin films deposited by reactive DC sputtering. J. Cryst. Growth 2018, 491, 120-125. [CrossRef]

13. Chen, X.B. Titanium dioxide nanomaterials and their energy applications. Chin. J. Catal. 2009, 30, 830-851. [CrossRef] 
14. Sikora, P.; Cendrowski, K.; Markowska-Szczupak, A.; Horszczaruk, E.; Mijowska, E. The effects of silica/titania nanocomposite on the mechanical and bactericidal properties of cement mortars. Constr. Build Mater. 2017, 150, 738-746. [CrossRef]

15. Sikora, P.; Horszczaruk, E.; Rucinska, T. The effect of nanosilica and titanium dioxide on the mechanical and self-cleaning properties of water-glass cement mortar. Procedia Eng. 2015, 108, 146-153. [CrossRef]

16. Mendoza, C.; Valle, A.; Castellote, M.; Bahamonde, A.; Faraldos, M. $\mathrm{TiO}_{2}$ and $\mathrm{TiO}_{2}-\mathrm{SiO}_{2}$ coated cement: Comparison of mechanic and photocatalytic properties. Appl. Catal. B 2014, 178, 155-164. [CrossRef]

17. Umar, I.G.; Abdul, H.A. Heterogeneous photocatalytic degradation of organic contaminants over titanium dioxide: A review of fundamentals, progress and problems. J. Photochem. Photobiol. C 2008, 9, 1-12.

18. Chen, J.; Kou, S.C.; Poon, C. Photocatalytic cement-based materials: Comparison of nitrogen oxides and toluene removal potentials and evaluation of self-cleaning performance. Build Environ. 2011, 46, 1827-1833. [CrossRef]

19. Ye, Q.; Mo, R.H.; Yu, Y.C.; Li, G.H.; Huang, Z.Z. Application of polymer cement mortar modified with nitrogen-doped nano-TiO 2 photocatalytic material. New Build. Mater. 2009, 36, 15-17.

20. Gao, J.W.; Yang, H.; Shen, Q.H. Research progress of $\mathrm{TiO}_{2}$ in green building materials. J. Ceram. 2007, 28, 237-239.

21. Wang, C.M.; Shi, H.S.; Li, Y. Research progress of nano- $\mathrm{TiO}_{2}$ photocatalytic functional building materials. New Chem. Mater. 2011, 39, 10-12.

22. Dong, R.; Shen, W.G.; Zhong, J.B.; Liao, G.; Chen, H.; Tan, Y. Research progress of photocatalytic self-cleaning concrete. Concrete 2011, 8, 62-65.

23. Meng, T.; Yu, Y.; Qian, X.; Zhan, S.; Qian, K. Effect of nano- $\mathrm{TiO}_{2}$ on the mechanical properties of cement mortar. Constr. Build Mater. 2012, 29, 241-245. [CrossRef]

24. Peng, F.P.; Ni, Y.R.; Zhou, Q.; Kou, J.H.; Lu, C.H.; Xue, Z.Z. New g- $\mathrm{C}_{3} \mathrm{~N}_{4}$ based photocatalytic cement with enhanced visible-light photocatalytic activity by constructing muscovite sheet $/ \mathrm{SnO}_{2}$ structures. Constr. Build Mater. 2018, 179, 315-325. [CrossRef]

25. Bossa, N.; Chaurand, P.; Levard, C.; Borschneck, D.; Miche, H.; Vicente, J.; Geantet, C.; Aguerre-Chariol, O.; Michel, F.M.; Rose, J.; et al. Environmental exposure to $\mathrm{TiO}_{2}$ nanomaterials incorporated in building material. Environ. Pollut. 2016, 220 Pt B, 1160-1170. [CrossRef]

26. Xu, J.; Teng, Y.; Teng, F. Effect of surface defect states on valence band and charge separation and transfer efficiency. Sci. Rep. 2016, 6, 32457. [CrossRef] [PubMed]

27. Teng, F.; Liu, Z.; Zhang, A.; Li, M. Photocatalytic performances of $\mathrm{Ag}_{3} \mathrm{PO}_{4}$ polypods for degradation of dye pollutant under natural indoor weak light irradiation. Environ. Sci. Technol. 2015, 49, 9489-9494. [CrossRef]

28. Teng, F.; Chen, M.; Li, N.; Hua, X.; Wang, K.; Xu, T. Effect of $\mathrm{TiO}_{2}$ surface structure on the hydrogen production activity of the Pt@CuO/TiO 2 photocatalysts for water splitting. Chem. Cat. Chem. 2014, 6, 842-847.

29. Wang, X.; Maeda, K.; Thomas, A.; Takanabe, K.; Xin, G.; Carlsson, J.M. A metal-free polymeric photocatalyst for hydrogen production from water under visible light. Nat. Mater. 2009, 8, 76-80. [CrossRef]

30. Yan, H.J.; Yang, H.X. TiO $2-$ g- $\mathrm{C}_{3} \mathrm{~N}_{4}$ composite materials for photocatalytic $\mathrm{H} 2$ evolution under visible light irradiation. J. Alloys Compd. 2011, 509, 126-129. [CrossRef]

31. Kang, H.W.; Lim, S.N.; Song, D.; Park, S.B. Organic-inorganic composite of g- $\mathrm{C}_{3} \mathrm{~N}_{4}-\mathrm{SrTiO}_{3}$ : $\mathrm{RH}$ photocatalyst for improved $\mathrm{H}_{2}$ evolution under visible light irradiation. Int. J. Hydrogen Energy 2012, 37, 11602-11610. [CrossRef]

32. Fu, Q.; Jiu, J.T.; Cai, K.; Wang, H.; Cao, C.B.; Zhu, H.S. Attempt to deposit carbon nitride films by electrodeposition from an organic liquid. Phys. Rev. B 1999, 59, 1693-1696. [CrossRef]

33. Zhao, H.; Yu, H.; Quan, X.; Chen, S.; Zhao, H.; Wang, H. Atomic single layer graphitic- $\mathrm{C}_{3} \mathrm{~N}_{4}$ : Fabrication and its high photocatalytic performance under visible light irradiation. Rsc. Adv. 2014, 4, 624-628. [CrossRef]

34. Sun, X.D.; Li, Y.Y.; Zhou, J.; Ma, C.H.; Wang, Y.; Zhua, J.H. Facile synthesis of high photocatalytic active porous $\mathrm{g}^{-} \mathrm{C}_{3} \mathrm{~N}_{4}$ with $\mathrm{ZnCl}_{2}$ template. J. Colloid Interface Sci. 2015, 451, 108-116. [CrossRef] [PubMed]

35. Wang, H.; He, W.; Dong, X.A.; Wang, H.; Dong, F. In situ FT-IR investigation on the reaction mechanism of visible light photocatalytic NO oxidation with defective $\mathrm{g}_{-} \mathrm{C}_{3} \mathrm{~N}_{4}$. Sci. Bull. 2018, 63, 117-125. [CrossRef]

36. Cui, W.; Li, J.; Cen, W.; Sun, Y.; Lee, S.C.; Dong, F. Steering the interlayer energy barrier and charge flflow via bioriented transportation channels in $\mathrm{g}-\mathrm{C}_{3} \mathrm{~N}_{4}$ : Enhanced photocatalysis and reaction mechanism. J. Catal. 2017, 352, 351-360. [CrossRef] 
37. Cui, W.; Li, J.; Dong, F.; Sun, Y.; Jiang, G.; Cen, W.; Lee, S.C.; Wu, Z. Highly effificient performance and conversion pathway of photocatalytic NO oxidation on SrO@clusters amorphous carbon nitride. Environ. Sci. Technol. 2017, 51, 10682-10690. [CrossRef]

38. Shi, L. Preparation and Properties of Carbon Nitride-Based Photocatalytic Materials. Ph.D. Thesis, Harbin Institute of Technology, Harbin, China, 2017.

39. Liao, G.; Chen, S.; Quan, X.; Yu, H.; Zhao, H. Graphene oxide modifified $g-\mathrm{C}_{3} \mathrm{~N}_{4}$ hybrid with enhanced photocatalytic capability under visible light irradiation. J. Mater. Chem. 2012, 22, 2721-2726. [CrossRef]

40. Hao, Q.; Niu, X.; Nie, C.; Hao, S.; Zou, W.; Ge, J.; Chen, D.; Yao, W. A highly efficient g-C $\mathrm{C}_{3} \mathrm{~N}_{4} / \mathrm{SiO}_{2}$ heterojunction: The role of $\mathrm{SiO}_{2}$ in the enhancement of visible light photocatalytic activity. Phys. Chem. Chem. Phys. 2016, 18, 31410-31418. [CrossRef]

41. Wang, D.; Yang, P.; Hou, P.K.; Zhang, L.N.; Zhang, X.Z.; Zhou, Z.H.; Xie, N.; Huang, S.F.; Cheng, X. Cement-based composites endowed with novel functions through controlling interface microstructure from $\mathrm{Fe}_{3} \mathrm{O}_{4} @ \mathrm{SiO}_{2}$ nanoparticles. Cem. Con. Com. 2017, 80, 268-276. [CrossRef]

42. Lin, B.; Xue, C.; Yan, X.; Yang, G.; Yang, G.; Yang, B. Facile fabrication of novel $\mathrm{SiO}_{2} / \mathrm{g}_{-} \mathrm{C}_{3} \mathrm{~N}_{4}$ core-shell nanosphere photocatalysts with enhanced visible light activity. Appl. Surf. Sci. 2015, 357, 346-355. [CrossRef]

43. Lei, J.; Ying, C.; Wang, L.; Liu, Y.D.; Zhang, J.L. Highly condensed g- $\mathrm{C}_{3} \mathrm{~N}_{4}$-modified $\mathrm{TiO}_{2}$ catalysts with enhanced photo degradation performance toward acid orange 7. J. Mater. Sci. 2015, 50, 3467-3476. [CrossRef]

44. Cao, S.; Low, J.; Yu, J.; Jaroniec, M. Polymeric photocatalysts based on graphitic carbon nitride. Adv. Mater. 2015, 27, 2150-2176. [CrossRef] [PubMed]

45. Feng, P.; Chang, H.L.; Liu, X.; Ye, S.X.; Shu, X.; Ran, Q.P. The significance of dispersion of nano-SiO 2 on early age hydration of cement paste. Mater. Des. 2020, 186, 108320. [CrossRef]

46. Shen, W.Z.; Ren, L.W.; Zhou, H.; Zhang, S.; Fan, W. Facile one-pot synthesis of bimedal mesepormm carbon nitride and its function as a lipase immobilization support. J. Mater. Chem. 2011, 21, 3890-3894. [CrossRef]

47. Wang, X.X.; Wang, S.S.; Hu, W.D.; Cai, J.; Zhang, L.; Dong, L. Synthesis and photocatalytic activity of $\mathrm{SiO}_{2} / \mathrm{g}-\mathrm{C}_{3} \mathrm{~N}_{4}$ composite photocatalyst. Mater. Lett. 2014, 115, 53-66. [CrossRef]

48. Tolman, R.C. The effect of droplet size on surface tension. J. Chem. Phys. 2004, 17, 333-337. [CrossRef]

49. Khandaker, M.; Anwar, H. Volcanic ash and pumice as cement additives: Pozzolanic, alkali-silica reaction and autoclave expansion characteristics. Cem. Concr. Res. 2005, 35, 1141-1144.

50. Wang, D.; Yang, P.; Hou, P.K.; Cheng, X. BiOBr@SiO 2 flower-like nanospheres chemically-bonded on cement-based materials for photocatalysis. App. Surf. Sci. 2018, 30, 539-548. 